\title{
IAMJ
}

INTERNATIONAL

AYURVEDIC

MEDICAL JOURNAL

\section{POST-COVID MANAGEMENT - A PRAGMATIC APPROACH OF PANCHAKARMA THERAPY}

\author{
Preeti Chaturvedi $^{1}$, Shalu Jain ${ }^{2}$, Anita Grewal ${ }^{3}$, Mukesh Kumar Sagar ${ }^{4}$ \\ ${ }^{1}$ Reader, ${ }^{2,3,4} \mathrm{PG}$ Scholar \\ PG Department of Panchakarma \\ Pt. Khushilal Sharma Government (Autonomous) Ayurveda College and Institute, Bhopal (MP), India
}

Corresponding Author: ayushpk5@gmail.com

\section{https://doi.org/10.46607/iamj2509072021}

(Published Online: July 2021)

Open Access

(C) International Ayurvedic Medical Journal, India 2021

Article Received: 24/06//2021 - Peer Reviewed: 25/06/2021 - Accepted for Publication: 25/06/2021

\section{Check for updates}

\section{ABSTRACT}

Corona is a highly contagious disease that attacks respiratory System breakdown immunity, produce various symptoms and can cause death according to the severity of diseases. In Ayurveda, two types of Vyadhis are mentioned i.e., Nija / Doshaj Vyadhi and Agantuj Vyadhi. The etiological factors, pathophysiology \& symptoms of corona disease can be correlated with Rajyakshyama. In an emergency, condition Panchakarma can be done in any season other than Sadharan Ritu by creating an artificial environment. We aim to improve pulmonary function and to prevent lungs complication like fibrosis and general symptoms like fatigue, insomnia etc. Panchakar$m a$ is a preventive, promotive well as a curative and cost-effective approach.

Keywords: Corona Virus, Panchakarma, Shodhan, Rajyakshama, Post-Covid

\section{INTRODUCTION}

In our Ayurvedic classics two types of Vyadhis are mentioned, Nija/Doshaj Vyadhi- it is of three types i.e., Vataj, Pittaj and Kaphaj. ${ }^{[1]}$ Agantuj Vyadhi- Vata is the main causative factor later Tridosh Prakop occur. $^{[2]}$ Corona is a highly contagious disease that attacks respiratory system breakdown immunity, pro- 
duce various symptoms and can cause death according to the severity of the disease. Post covid 19 can be not only in prolonged illness but also in patients without an underline chronic medical condition. $R a$ jyakshma is Madhyam Roga Marga. ${ }^{[3]}$ Tridoshaj Vyadhi. Sapta Dhatus (Ras, Rakta, Mamsa, Meda Asthi, Majja and Shukra) are involved in the manifestation of Rajyakshama. The etiological factors, pathophysiology \& symptoms of corona disease can be correlated with Rajyakshma.

\section{AIM \& OBJECTIVE}

- To understand the post covid symptoms according to Ayurveda as well as modern Science.

- To describe the safe \& cost-effective Panchakarma therapy for post covid patients.

\section{ANALOGY OF RAJAYKSHAMA WITH POST COVID ILLNESS:}

After acute covid-19 illness recovered Patients may continue with a wide variety of signs \& symptoms, which may be prolonged and persistent symptoms. These symptoms can be divided into two categories i.e., common symptoms and less common symptoms. The post covid symptoms are similar to symptoms that are described in Rajyakshma. Coronavirus disease may be the result of a faulty dietary regimen that leads to the vitiation of Tridosha (Vishmashan/ improper dietary habits). In Vishmashan Janya Rajyakshma ${ }^{[4]}$ (Aupsargik Vyadhi), due to the Vishamashan also the vitiation of Tridosh occurs. Rajayakshama and coronavirus diseases are Aupsargik (contagious) and spread from human to human.

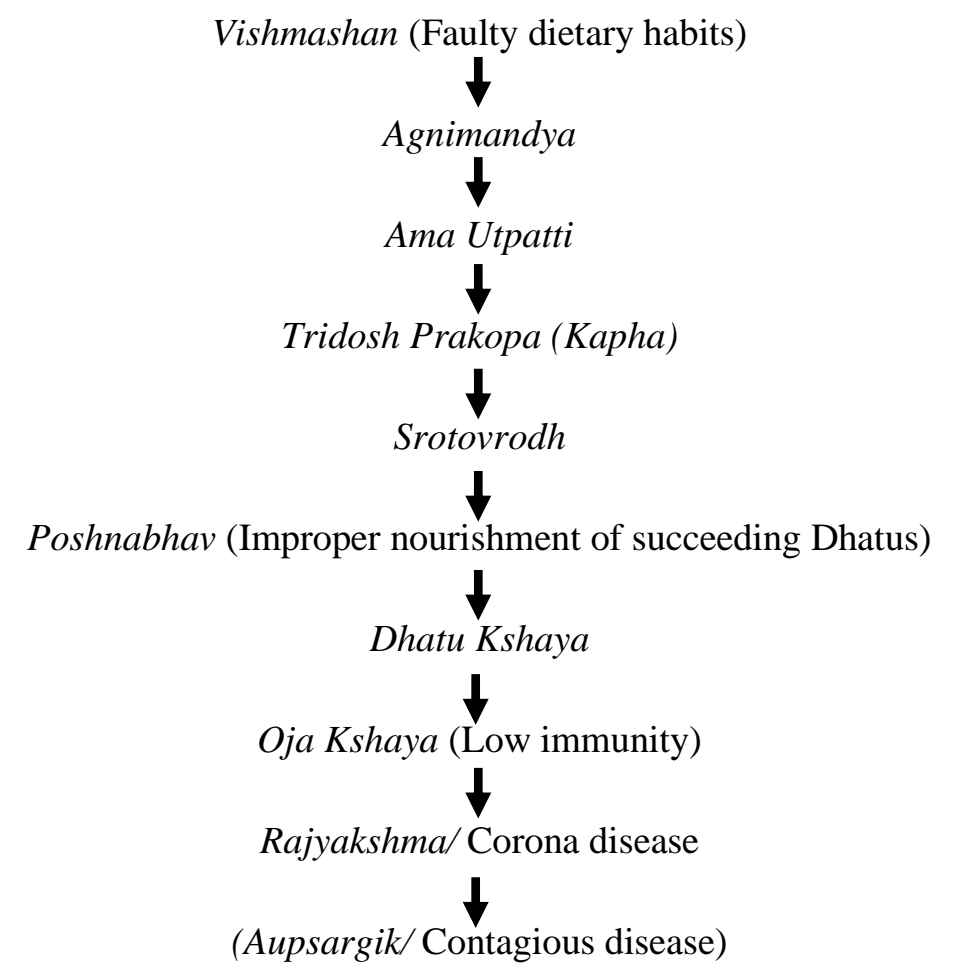

Table 1:

\begin{tabular}{|c|c|}
\hline Symptoms of Post covid ${ }^{[5]}$ & $\begin{array}{lll}\text { Symptoms } & \text { of } & R a- \\
\text { jyakshama }^{[6]} & & \end{array}$ \\
\hline Rhinitis & Pratishyaya \\
\hline Cough & Kasa \\
\hline Excessive expectoration & Chhardi \\
\hline Low/ Absence/ Altered taste & Arochak \\
\hline
\end{tabular}

\begin{tabular}{|l|l|}
\hline Fever & Jwara \\
\hline Headache & Shirshool \\
\hline Hoarseness of voice & Swarbhed/ Swarbhramsh \\
\hline Congestion of throat & Kanhthoddhvans \\
\hline Malaise & Angamarda \\
\hline Pain at the shoulder region & Anshmarda \\
\hline Difficulty in breath & Shwasa \\
\hline
\end{tabular}




\begin{tabular}{l|l}
\hline Improper digestion & Avipaka \\
\hline $\begin{array}{l}\text { Chest pain/ side pain } \\
\text { Altered Neurocognitive Be- } \\
\text { havior }\end{array}$ & Parshvashool \\
\hline
\end{tabular}

PROPOSED PANCHAKARMA: Post covid recovered patients can be posted for the Panchakarma therapy. According to Ayurveda, there will be Dhatukshsya and Agnimandya. To correct the Dhatukshaya Mridu Shodhan and Dhatuposhan Chikitsa \& for the Agnimandya Deepan, Pachana Chikitsa is needed.

According to the Acharya Sushruta in Durbal Purush, if Mridu Kostha and movable Dosha we can give Mridu Samshodhana. ${ }^{[7]}$ According to Acharya Charka, by Desh, Kaal and Bala one must do restricted Karma and leave the canonical Karma.

1. Shadangpaniya ${ }^{[8]}$ : (Musta, Parpatak, Ushir, Chandan, Sugandhbala, Sunthi)- it is for correcting the metabolism, digestive system and give relief in thirst.

2. Snehan ${ }^{[9]}$ : Shaman Snehanpan- Chautarbhaktikam (Ghrita after food) - to cure Sheershool, Parshvashool, Anshshool, Kasa, Shwas. Ex. Bala Ghrita, Dashmool Ghrita, Jivantyadi Ghrita

3. Abhyanga ${ }^{[10]}$ : To help rejuvenation of the body. Ex. Mishrak Sneha.

4. Parisheka ${ }^{[11]}$ : To provide firmness to the tissues. Ex. Bala, Guduchi, Madhuka Kwatha, Vata Shamak Aushadhi Kwatha)

5. Avagahan ${ }^{[12]}$ : To relieve stiffness, pain and swelling. Ex. Dugdha, Bala, Guduchi, Madhuka Kwatha.

6. Udvartan [13]: To remove obstruction of Srotasa. Ex. Shatavari, Punarnava, Bala, Sarshap.

7. Shodhnarth Snehapana [14]: To prepare the body for Shodhan Karma Ex.- Panchkoladi Ghrita, Jivantyadi Ghrita, Rasna Ghrita, Bala Ghrita and Kharjuradi Ghrita.

8. Nadi Swedan ${ }^{[15]}$ : To regaining the strength.

1) Ksheer Dhoom with Vatahar Dravya.

2) Sneha with Kanji.
9. Upnah Swedan [16]: To induce sweating and bring Doshavilayan. Ex. Jivanti, Shatpushpa, Bala, Madhuk, Vacha, Veshawar, Vidari + Chatursneha.

10. Lepa/ Pradeha [17]: (Shatpushpa, Madhuka, Kooth, Tagar, Chandana + Ghrita), (Bala, Rasna, Til, Sarpi, Madhuka, Neelkamal + Ghrita).

11. Vamana ${ }^{[18]}$ : Vamana procedure done with Dugdha + Madanphala (Doshadhikya.

12. Virechana ${ }^{[19]}$ : Virechana procedure done with Trivrita, Amaltas (Aragvadh), Sharkra + Madhu + Ghrita + Dugdha + Sattu. Virechan with Draksha, Vidari, Kashmari and Mamsh.

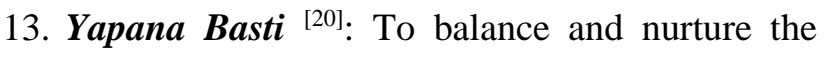
Vata.

1) Hrishva Panchamuladi Yapana Basti ${ }^{[21]}$ : Guda, Sandhava, Ghrita, Taila, Madanphala Kalka, Laghupanchamool Kwatha And Dugdha.

2) Baladi Yapna Basti ${ }^{[22]}$ : Madhu, Saindhava, Ghrita, Kalka \{Madhuk-Madanphala\}, Kwatha \{Balamool, Vidari, Darbhool, Mridvika, Yava + Aja Dugdha\}.

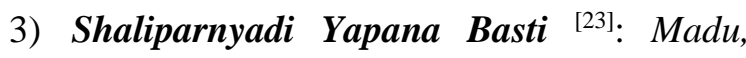
Saindhava, Ghrita, Kalka \{Pippali, Madhuka, Utpal\}, Kwatha \{Shalparni, Prishparn, Gokshura, Kashmarya, Parushak, Kharjur, Madhuk Pushpa + Aja Dughda.

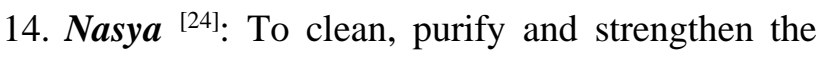
nasal passage and head. Pratimarsh- Daily Practice with Anu Taila, Til Taila and Sarshapa Taila.

1) Shodhana Nasya.

2) Navana- Shodhan- Bala, Vidarigandhadi Gana Siddh Ghrita + Nasya with Saindhav.

15. Jalaukavcharan ${ }^{[25]}$ : Avgadhe Jalaulasyat - To remove impure blood.

16. Dhoompana ${ }^{[26]}$ : To remove the stagnant Kapha.

1) Agru

2) Haridra, Tejpatra, Erandmool, Laksha, Manshila, Deodaru, Hartal and Jatamanshi 
17. Kavala ${ }^{[27]}$ : It can be advised in MukhvairasyaTwice a day- Dalcheeni, Ela, Dhanyka, Mustaka and Aamlaka.

18. Shirodhara ${ }^{[28]}$ : To enhance the efficiency of the nervous system. Ex. (Bala, Guduchi, Madhuka Kwatha), Vata Shamak Aushadhi Kwatha.

\section{DISCUSSION AND CONCLUSION}

Post-Covid Complications have become a major cause of worry for doctors as well as a patient across the world. Life after covid infection may not be smooth sailing. The information providing in this research paper is useful to the patient and Panchakarma therapy will help in saving the patient from long term complications, the physical mental health of the patient will be good, and the patient doesn't have to be admitted to the hospital again.

\section{REFERENCES}

1. Shastri Kashinath, Chaturvedi Gorakhnath edited Charak Samhita of Agnivesha, revised by Charaka and Dridhbala, part I, Chaukhambha Bharati Academy, Varanasi. Reprint., 2014; Sutra Sthana 20/3; page no; 394.

2. Shastri Kashinath, Gorakhnath edited Charak Samhita of Agnivesha, revised by Charaka and Dridhbala, Part I, Chaukhambha Bharati Academy, Varanasi. Reprint., 2014; Sutra Sthana 20/7; page no; 396.

3. Shastri Kashinath, Chaturvedi Gorakhnath edited Charak Samhita of Agnivesha, revised by Charaka and Dridhbala, part I, Chaukhambha Bharati Academy, Varanasi. Reprint., 2014; Sutra Sthana 11/48; page no; 235.

4. Shastri Kashinath, Chaturvedi Gorakhnath edited Charak Samhita of Agnivesha, revised by Charaka and Dridhbala, part I, Chaukhambha Bharati Academy, Varanasi. Reprint., 2014; Nidan Sthana 6/10; page no; 653 .

5. Francesca_salamanna et.al/NCBI/ post-covid-19 syndrome: the persistent symptoms at the post-viral stage of the disease. A systematic review of the current data/ Front Med (Lausanne). 2021; 8: 653516./Published online 2021 May 4

6. Shastri Kashinath, Chaturvedi Gorakhnath edited Charak Samhita of Agnivesha, revised by Charaka and Dridhbala, part I, Chaukhambha Bharati Academy, Varanasi. Reprint., 2014; Nidan Sthana 6/14; page no; 655 .

7. Ambikadutt Shastri, Hindi Commentary Chaukhambha Sanskirt Sansthan Varanasi, Susruta Samhita, Sutra Sthana chapter 39/12, 2012; pg 192.

8. Shastri Kashinath, Chaturvedi Gorakhnath edited Charak Samhita of Agnivesha, revised by Charaka and Dridhbala, part II, Chaukhambha Bharati Academy, Varanasi. Reprint., 2014; Chikitsa Sthana 1/145; page no; 135

9. Shastri Kashinath, Chaturvedi Gorakhnath edited Charak Samhita of Agnivesha, revised by Charaka and Dridhbala, part II, Chaukhambha Bharati Academy, Varanasi. Reprint., 2014; Shikitsa Sthana 8/81; page no; 289

10. Astangahrdayam, edited by Dr Brahmanand Tripathi, Chaukhamba Sanskrit Pratishthan Prakashana, Delhi, 2009 Chikitsa Sthana 5/65; p. 443.

11. Shastri Kashinath, Chaturvedi Gorakhnath edited Charak Samhita of Agnivesha, revised by Charaka and Dridhbala, part II, Chaukhambha Bharati Academy, Varanasi. Reprint., 2014; Chikitsa Sthana 8/72; page no; 288

12. Shastri Kashinath, Chaturvedi Gorakhnath edited Charak Samhita of Agnivesha, revised by Charaka and Dridhbala, part II, Chaukhambha Bharati Academy, Varanasi. Reprint., 2014; Chikitsa Sthana 8/173; page no; 301

13. Astangahrdayam, edited by Dr Brahmanand Tripathi, Chaukhamba Sanskrit Pratishthan Prakashana, Delhi, 2009 Chikitsa Sthana 5/78; p.444

14. Astangahrdayam, edited by Dr Brahmanand Tripathi, Chaukhamba Sanskrit Pratishthan Prakashana, Delhi, 2009 Chikitsa Sthana 5; p. 438-439

15. Shastri Kashinath, Chaturvedi Gorakhnath edited Charak Samhita of Agnivesha, revised by Charaka and Dridhbala, part II, Chaukhambha Bharati Academy, Varanasi. Reprint., 2014; Chikitsa Sthana 8/73; page no; 288.

16. Shastri Kashinath, Chaturvedi Gorakhnath edited Charak Samhita of Agnivesha, revised by Charaka and Dridhbala, part II, Chaukhambha Bharati Academy, Varanasi. Reprint., 2014; Chikitsa Sthana 8/76; page no; 289

17. Shastri Kashinath, Chaturvedi Gorakhnath edited Charak Samhita of Agnivesha, revised by Charaka and Dridhbala, part II, Chaukhambha Bharati Academy, Varanasi. Reprint., 2014; Chikitsa Sthana 8/77; page no; 289

18. Astangahrdayam, edited by Dr Brahmanand Tripathi, 
Chaukhamba Sanskrit Pratishthan Prakashana, Delhi, 2009 Chikitsa Sthana 5/2; p. 436.

19. Astangahrdayam, edited by Dr Brahmanand Tripathi, Chaukhamba Sanskrit Pratishthan Prakashana, Delhi, 2009 Chikitsa Sthana 5/4; p. 437

20. Shastri Kashinath, Chaturvedi Gorakhnath edited Charak Samhita of Agnivesha, revised by Charaka and Dridhbala, part II, Chaukhambha Bharati Academy, Varanasi. Reprint., 2014; Sidhi Sthana 12/15-8; page no; 1099

21. Shastri Kashinath, Chaturvedi Gorakhnath edited Charak Samhita of Agnivesha, revised by Charaka and Dridhbala, part II, Chaukhambha Bharati Academy, Varanasi. Reprint., 2014; Sidhi Sthana 12/15-8; page no; 1099

22. Shastri Kashinath, Chaturvedi Gorakhnath edited Charak Samhita of Agnivesha, revised by Charaka and Dridhbala, part II, Chaukhambha Bharati Academy, Varanasi. Reprint., 2014; Sidhi Sthana12/15-11; page no; 1099

23. Shastri Kashinath, Chaturvedi Gorakhnath edited Charak Samhita of Agnivesha, revised by Charaka and Dridhbala, part II, Chaukhambha Bharati Academy, Varanasi. Reprint., 2014; Sidhi Sthana 12/1511; page no; 1099

24. Shastri Kashinath, Chaturvedi Gorakhnath edited Charak Samhita of Agnivesha, revised by Charaka and Dridhbala, part II, Chaukhambha Bharati Academy, Varanasi. Reprint., 2014; Chikitsa Sthana 8/90; page no; 290

25. Ambikadutt Shastri, Hindi Commentary Chaukhambha Sanskirt Sansthan Varanasi, Susruta Samhita, Sutra Sthana Chapter 13, 2012.

26. Astangahrdayam, edited by Dr Brahmanand Tripathi, Chaukhamba Sanskrit Pratishthan Prakashana, Delhi, 2009 Chikitsa Sthana 5/69; p. 443.

27. Shastri Kashinath, Chaturvedi Gorakhnath edited Charak Samhita of Agnivesha, revised by Charaka and Dridhbala, part II, Chaukhambha Bharati Academy, Varanasi. Reprint., 2014; Chikitsa Sthana 8/136; page no; 296.

28. Shastri Kashinath, Chaturvedi Gorakhnath edited Charak Samhita of Agnivesha, revised by Charaka and Dridhbala, part II, Chaukhambha Bharati Academy, Varanasi. Reprint., 2014; Chikitsa Sthana 8/140; page no; 297.

\section{Source of Support: Nil \\ Conflict of Interest: None Declared}

How to cite this URL: Preeti Chaturvedi et al: Post-Covid Management - A Pragmatic Approach Of Panchakarma Therapy. International Ayurvedic Medical Journal \{online\} 2021 \{cited July 2021\} Available from: http://www.iamj.in/posts/images/upload/1480_1484.pdf 